\title{
E-mobility Infrastructure in the Górnośląsko - Zagłębiowska Metropolis, Poland, and Potential for Development
}

\author{
Elżbieta Macioszek \\ Silesian University of Technology \\ Krasińskiego 8 Street, 40-019 Katowice, Poland \\ elzbieta.macioszek@polsl.pl
}

\begin{abstract}
Electromobility is a set of activities related to the use of electric vehicles, as well as technical and operational EV solutions, technologies and charging infrastructure, as well as social, economic and legal issues pertaining to the designing, manufacturing, purchasing and using electric vehicles. The article presents results of the survey on e-mobility infrastructure in the GórnośląskoZagłębiowska Metropolis, Poland, and potential for development.
\end{abstract}

Keywords: Electromobility, Electric vehicles, Górnośląsko-Zagłębiowska Metropolis.

\section{Introduction}

The growing interest in electric vehicles is the effect of a sustainable transport development, objectives of which presented in the White Paper should be adopted by all EU member states. At the moment, in Poland, comparing to other nation countries of western Europe, the market of electric vehicles is still in its early stages of development. Thus, Polish roads are frequented by much fewer electric vehicles than in many other European countries. The main reasons contributing to the situation in Poland regarding the number of electric cars include relatively high prices of electric cars, shortage of infrastructure, e.g. small number of charging stations, and technological limitation of a short range of electric vehicles.

However, following countries where electric vehicles are a standard component of the vehicle fleet, also Poland is expected to witness a decrease in prices of electric vehicles and the development of charging infrastructure. In recent years, in Poland, a number of scientific papers have been published on electromobility and electric vehicles (e.g. [1-7]). According to the Law on electromobility and alternative fuels of $11^{\text {th }}$ January 2018 (JoL 2018 item 317) [8], Polish cities are required to develop electromobility plans. According to Art. 60.1. of the Law, the minimum number of charging points until 31.12.2020 in public access charging stations in various municipalities should be as follows [8]:

- 1000 - in municipalities with population exceeding 1,000,000 people and at least 600,000 cars registered, and at least 700 vehicles per 1000 inhabitants,

- 210 - in municipalities with population exceeding 300,000 people and at least 200,000 cars registered, and at least 500 vehicles per 1000 inhabitants,

- 100 - in municipalities with population exceeding 150,000 people and at least 95,000 cars registered, and at least 400 vehicles per 1000 inhabitants,

- 60 - in municipalities with population exceeding 100,000 people and at least 60,000 cars registered, and at least 400 vehicles per 1000 inhabitants.

While analysing time needed for the implementation of various activities we may assume that the majority of cities in Poland will fail to reach the goals regarding charging stations by the statutory deadline. Previous experience has shown that investment in charging stations take at least two years, of which the vast majority of time needed is spent on formalities. Although cities are still at the early stage of planning the location of charging infrastructure, they are not subject to any sanctions in case of failure to perform. Until 15.01.2020, cities are required to develop a report on the number of charging stations built and planned until the end of the preceding year. In case there are too few of them, they will have to develop plans for building further charging stations. It is expected that local distribution system operators will take care of the investment. The group includes four state-owned power utilities, such as Tauron, PGE, Energa, Enea. 
The article presents results of the e-mobility infrastructure survey in the Górnośląsko-Zagłębiowska Metropolis, Poland, including the potential for development.

\section{Guidelines for the operation of electric vehicle charging infrastructure}

Greenway Polska specified technical and design guidelines for EV charging infrastructure [9]. In case charging infrastructure is situated in public space it is advisable to do the following [9]:

- in densely developed areas without guarded car parks, certain percentage of parking places should be earmarked for charging stations (10-20\%),

- design charging hubs. Such hubs are locations with a series of multiple charging points next to each other (e.g. 10-20). Such hubs facilitate access to the power network due to the economy of sale (it is easier and cheaper to build a series of charging points, rather than develop individual charging points in various locations), and shorter queues of cars waiting for charging. The establishing of such hubs in the vicinity of companies or residential estates facilitates their convenient use by citizens,

- install public AC charging stations in case such a demand is expressed by citizens. It expresses a market oriented bottomup approach which proved efficient in Amsterdam (one of leading cities in the Europe promoting the use of electric vehicles),

- special attention should be put to charging of electric taxes and other utility vehicles. Such users can generate a considerable stream of revenue and they occupy charging stations for a longer period,

- in densely populated locations, it is necessary to coordinate the development of charging stations to optimize charging infrastructure (and perhaps also certain charging hubs).

In case of developing charging infrastructure for electric vehicles next to multi-family buildings and office facilities, it is advisable to do the following [9]:

- require administrators of private car parks/garages to allow individuals to add or improve cabling to install and operate charging stations at their parking places,

- require private car parks/garages to provide a certain number of charging stations,

- educate major decision makers, such as members of citizen councils, administrators etc. as regards technical and safety requirements, as well as advantages of charging infrastructure (e.g. California),

- encourage companies to install charging points in their office facilities/garages (e.g. France and Great Britain),

- require new buildings to be adjusted for fitting charging stations. During designing and building, this does not involve any major cost. Such improvements may include new cables for charging stations placed in walls, floors or ceilings in the vicinity of car park facilities (e.g. London and number of cities in California). The EU drafted regulations regarding the implementation of the above solutions by 2025. Moreover, new building projects should include charging stations for electric vehicles, and their number should correspond to certain percentage of all parking places. Enough that $10 \%$ of parking places are designated to enable charging of electric vehicles and are fitted with relevant vertical and horizontal signs.

\section{Identification of e-mobility infrastructure in the Górnośląsko-Zagłębiowska Metropolis, Poland}

As regards the accessibility of charging infrastructure, a crucial role is played by time needed to access a charging location. Thus, the primary factor decisive regarding the accessibility of charging points is their number and deployment. Fig. 1 presents results of the survey on public access charging points in the Górnośląsko-Zagłębiowska Metropolis.

It is assumed that the impact area of a given charging point is a range from which prospective users of electric cars can walk to a charging point without much fatigue. In Poland, the distance is not regulated by any planning standards. Regarding this particular issue, the survey and conducted analyzed (Fig. 1) indicates unsatisfactory transport accessibility (several charging points for electric vehicles per each city, distributed location of charging points). 


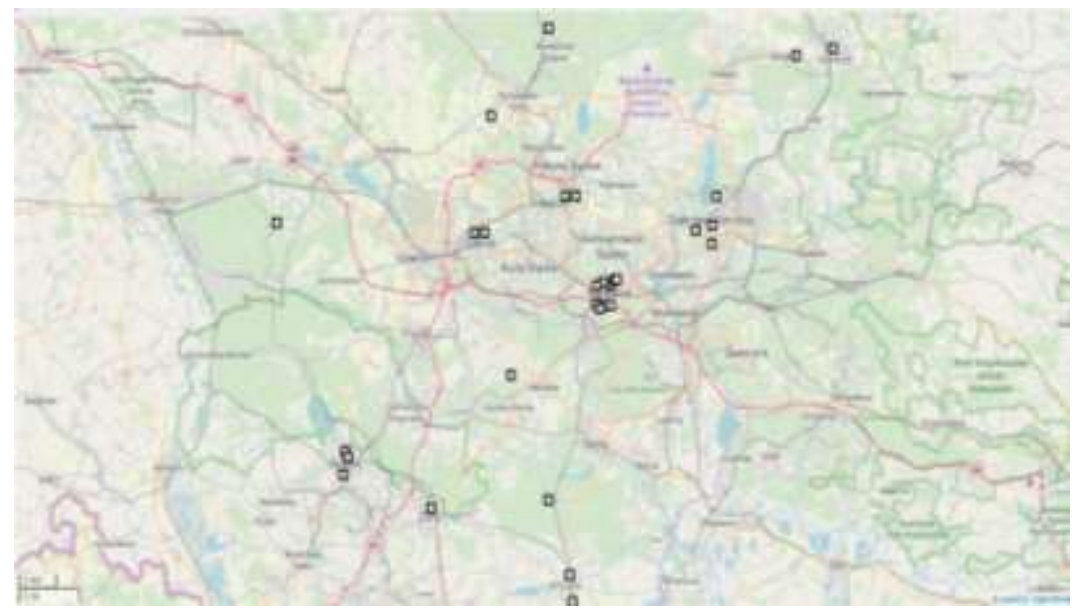

Fig. 1: Survey of public access charging points for electric vehicles in Górnośląsko-Zagłębiowska Metropolis, Poland.

\section{Prospects for development in electromobility - strategic documents on the future development in cities comprising the Górnośląsko - Zagłębiowska Metropolis}

Following other cities in the world and in Poland, the Górnośląsko - Zagłębiowska Metropolis show growing interest in electromobility. It promotes economic development in the region and contributes to a growing number of charging stations for electric vehicles. Considering the above, strategic planning documents by the local government have set directions for the development of electromobility and the use of electric vehicles. Some of the objectives are as follows [10-14]:

- promoting electric and hybrid vehicles by exempting them from specific requirements restricting access to city centres, free parking etc.,

- supporting projects related to the use of low emission vehicles (hybrid and electric cars),

- promoting alternative low emission fuel buses, e.g. with electric, hydrogen and hybrid engines. Apart from zero emission, electric buses have lower noise emission, which is particularly important in leisure areas and pedestrian zones,

- supporting the use of low emission vehicles, in particular exhaust gas emission and change of propulsion to hybrid, alternative fuels and finally electric engines in line with EU recommendations,

- gradually shifting to more environmentally friendly transport. The use of electric, hydrogen and hybrid engines not only reduces pollution, but also noise. This means that in cities the majority of cargo could be transported at night,

- gradually eliminating conventional cars from our cities (reduction by half until 2030 and total ban until 2050); this process, however, need to be accompanied by the development of infrastructure to replenish fuel and charge batteries.

It should be emphasised that strategic documents setting new directions for future development of electromobility and the use of electric vehicles in cities of the Silesia Region state that the development should coincide with much environmental focus to reduce potential threat to health and life of citizens.

\section{Conclusions}

There are many challenges for the development of charging infrastructure in the Górnośląsko-Zagłębiowska Metropolis, such as purchase/lease land for charging stations, optimised deployment, use of existing power infrastructure, and funding for the development of charging stations. Yet another challenge is still long charging time. For this reason, the development of EV charging capacity faces limitations of the transport network and those limitations are an important factor determining locations of such stations. While looking for optimised locations, one should consider such factors as time necessary to charge an electrical vehicle (minimum 30 minutes), travelling range, number of electric vehicles in a given area, density of population, availability of parking places (to be designated for EV charging), accessibility of power infrastructure, land ownership structure and distances between charging points in various agglomerations to ensure the most convenient travelling between cities. 


\section{Acknowledgements}

The present research has been financed from the means of the National Centre for Research and Development as a part of the international project within the scope of ERA-NET CoFund Electric Mobility Europe Programme "Electric travelling - platform to support the implementation of electromobility in Smart Cities based on ICT applications".

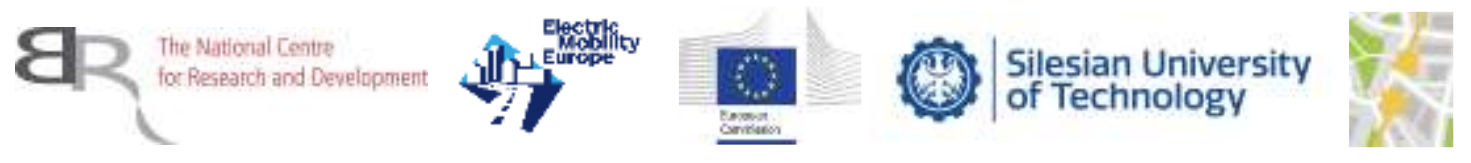

\section{References}

[1] J. Murawski and E. Szczepański, "Perspektywy rozwoju elektromobilności w Polsce". Logistyka, vol. 4, pp. 2249-2258, 2014.

[2] G. Sierpiński, M. Staniek, E. Macioszek, "Standardisation of travel planners and use of a return channel," Proceedings of the 2nd World Congress on Civil, Structural, and Environmental Engineering, Barcelona, 2017, Paper No. ICTE 121.

[3] G. Sierpiński, "Theoretical Model and Activities to Change the Modal Split of Traffic," Communications in Computer and Information Science, vol. 329, pp. 45-51, 2012.

[4] E. Macioszek, "Freight Transport Planners as Information Elements in the Last Mile Logistics", in Integration as Solution for Advanced Smart Urban transport Systems. Advances in Intelligent Systems and Computing 844, G. Sierpiński, Ed. Switzerland: Springer 2019, pp. 242-251.

[5] E. Macioszek, "First and last mile delivery - problems and issues", in Advanced Solutions of Transport Systems for Growing Mobility. Advances in Intelligent Systems and Computing 631, G. Sierpiński, Ed. Switzerland: Springer 2018, pp. 147-154.

[6] G. Sierpiński, M. Staniek, Heuristic approach in a multimodal travel planner to support local authorities in urban traffic management, Transportation Research Procedia, vol. 27, 2017, pp. 640-647.

[7] M. Staniek, E. Macioszek, G. Sierpiński, Travel planning concept taking road infrastructure condition into account, World Congress on Civil, Structural, and Environmental Engineering, 2017, Paper No. ICTE 123.

[8] Kancelaria Sejmu: Ustawa z dnia 11 stycznia 2018 r. o elektromobilności i paliwach alternatywnych (Dz.U.2018 poz. 317).

[9] A, Fishbone and Z. Shahan and P. Badik and all. Infrastruktura ładowania pojazdów elektrycznych. Wytyczne dla miast. Warszawa, Greenway 2017.

[10] Program Ochrony Środowiska dla Województwa Śląskiego do roku 2019 z uwzględnieniem perspektywy do roku 2024. Urząd Marszałkowski Województwa Śląskiego Katowice, kwiecień 2015 r.

[11] Plan Transportowy Województwa Śląskiego. Sejmik Województwa Śląskiego. Śląskie. Pozytywna Energia 2014.

[12] Plan zrównoważonego rozwoju publicznego transportu zbiorowego dla Powiatu Gliwickiego (Plan Transportowy). Starostwo Powiatowe w Gliwicach. Warszawa 2014.

[13] Plan Zrównoważonego Rozwoju Publicznego Transportu Zbiorowego dla Międzygminnego Związku Komunikacji Pasażerskiej w Tarnowskich Górach na lata 2013 - 2023. Tarnowskie Góry - Katowice 2013.

[14] Plan Zrównoważonego Rozwoju Publicznego Transportu Zbiorowego (PZRPTZ) dla m. Jaworzno. Gmina Jaworzno Miejski Zarząd Dróg i Mostów z Siedzibą w Jaworznie. Katowice 2013 r. 